\title{
Use of chloramine-T and two dyes in the sensitive determination of stavudine in pharmaceuticals
}

\author{
Kanakapura Basavaiah" ${ }^{1 *}$, Veeraiah Ramakrishna ${ }^{2}$, Urdigere Rangachar Anilkumar ${ }^{1}$ \\ ${ }^{1}$ Department of Chemistry, University of Mysore, India, ${ }^{2}$ Department of Drugs Control, \\ Govt. College of Pharmacy, India
}

*Correspondence:

K. Basavaiah

Department of Chemistry

University of Mysore

Manasagangotri, Mysore-570 006,

India

E-mail: basavaiahk@yahoo.co.in
Three new methods are described for the assay of stavudine (STV) in bulk drug and in dosage forms using chloramine-T (CAT) and two dyes, methyl orange and indigocarmine, as reagents. Titrimetry involves treating STV with a measured excess of CAT in hydrochloric acid medium, and after the oxidation of STV is judged to be complete, the unreacted oxidant is determined iodometrically. Spectrophotometric methods entail the addition of a known excess of CAT to STV in hydrochloric acid medium followed by determination of residual oxidant by reacting with a fixed amount of either methyl orange and measuring the absorbance at $520 \mathrm{~nm}$ (Method A) or indigo carmine and measuring the absorbance at $610 \mathrm{~nm}$ (Method B). In all the methods, the amount of CAT reacted corresponds to the amount of STV. In titrimetric method, the reaction follows 1:1 stoichiometry (STV: CAT), and is applicable over the range 1.5-10 $\mathrm{mg}$ of STV. In spectrophotometric methods, the absorbance is found to increase linearly with concentration of STV. The systems obey Beer's law for 0.2-2.0 and 1.0-10.0 $\mu \mathrm{g} / \mathrm{mL}$ for method $A$ and method $B$, respectively. The apparent molar absorptivities are calculated to be $5.7 \times 10^{4}$ and $1.5 \times 10^{4} \mathrm{~L} / \mathrm{mol} / \mathrm{cm}$ for method $A$ and method $B$, respectively, and the corresponding Sandell sensitivity values are 0.004 and $0.015 \mu \mathrm{g} / \mathrm{cm}^{2}$. The limits of detection and quantification are reported for both methods. Intra-day and inter-day precision and accuracy of the developed methods were evaluated as per the current ICH guidelines. The methods were successfully applied to the assay of STV in tablet and capsule formulations and the results were compared with those of a reference method by applying Student's t-test and F-test. No interference was observed from common tablet adjuvants. The accuracy and reliability of the methods were further ascertained by performing recovery experiments via standard-addition method.
Uniterms

- Stavudine

- Titrimetry

- Spectrophotometry

- Chloramine-T 


\section{INTRODUCTION}

Stavudine (STV), chemically known as $2^{1}-3^{1}$ didehydro $-2^{1}-3^{1}$ - dideoxythymidine (Figure 1 ), is a nucleoside analog reverse transcriptase inhibitor (NARTI) active against HIV (Merck Index, 1996). STV is converted intracellularly to triphosphate which stops the DNA synthesis of retroviruses through competitive inhibition of reverse transcriptase and incorporation into viral DNA. It is the fourth antiretroviral drug in the market and is used in the treatment of HIV infection. The drug is official in United States Pharmacopeia (USP, 2006). which describes high performance liquid chromatographic procedures for bulk drug and tablets.

A number of methods based on high performance liquid chromatography (Bezy et al. 2005; Verweij-van Wissen et a1. 2005; Contreras et al. 2004), liquid chromatography-tandem mass spectrometry (Compain et al., 2005; Huang et al., 2004; Raices et al., 2003, Fan et al., 2002; Weisner et al., 2002), micellar electrokinetic chromatography (Fan and Stewart. 2002) and electrophoresis (Pereira et al., 2005) are known for the quantitative determination of STV in biological matrices such as blood plasma, blood serum and human cells. Several chromatographic techniques including HPLC (Dunge et al., 2005; Djurdjevic et al., 2004; Zhang et al.,
2003; Sablon et al., 2004; Pai and Desai. 2003; Rezk et al., 2003), HPTLC (Wankhede et al., 2005; Kaul et al., 2005) and LC-MS (Volosov et al., 2002), have been used for the determination of STV in pharmaceuticals. The drug has also been assayed by mass spectrometry (Soldin, 2004) and UV-spectrophotometry (Sankar et al., 2002).

Despite its long history and established versatility, no titrimetric method has yet been reported for the determination of STV in pharmaceuticals. Visible spectrophotometry, because of its simplicity, speed, sensitivity, reasonable accuracy and precision, and cost-effectiveness, continues to be the preferred technique in laboratories of developing and underdeveloped nations, which can illafford expensive chromatographic and related techniques. Three procedures (Sarma et al., 2002) have been reported for the assay of STV in pharmaceuticals using Potassium permanganate-Fast Green FCF, permanganate/periodate3-methylbenzothiazolinone hydrazone (MBTH) and iron(III)chloride-ferricyanide as reagents. The same authors (Sarma et al., 2002) have used three more reagents, N-bromosuccinimide (NBS)-celestine blue, cobalt thiocyante and ammonium molybdate for the spectrophotometric determination of STV. A method based on oxidative-coupling reaction (Sankar et al., 2002) involving the use of iron (III)-MBTH is also found in the literature. But, these methods suffer from one or the other
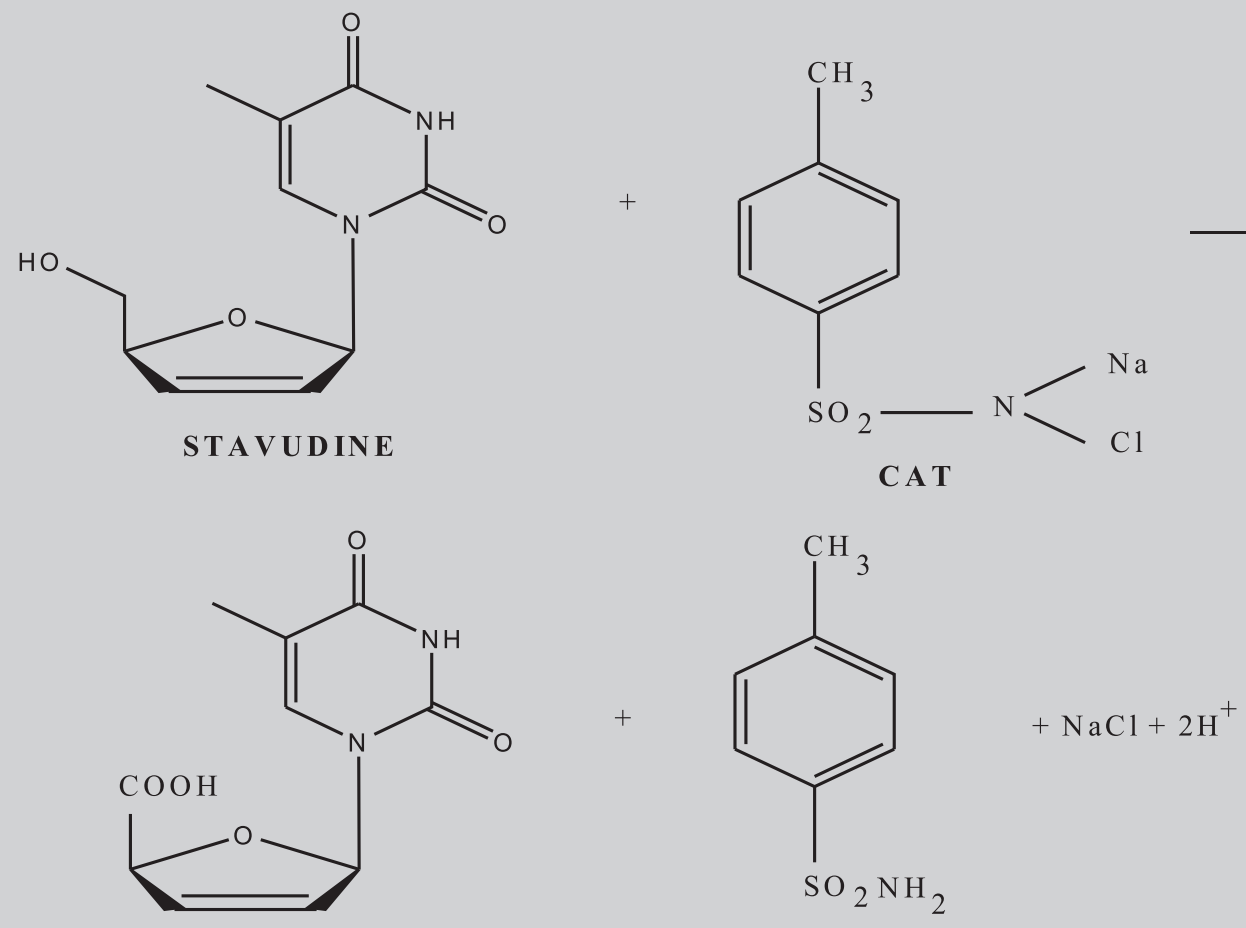

FIGURE 1 - Tentative reaction scheme. 
TABLE I - Comparison of performance characteristics of proposed methods with the existing spectrophotometric methods

\begin{tabular}{|c|c|c|c|c|c|c|}
\hline $\begin{array}{l}\text { Sl } \\
\text { No. }\end{array}$ & Reagent* & $\lambda_{\text {max }}, n m$ & $\begin{array}{l}\text { Linear range, } \\
\mu \mathrm{g} / \mathrm{mL}\end{array}$ & $\begin{array}{l}\in, \\
\mathrm{L} / \mathrm{mol} / \mathrm{cm}\end{array}$ & Remarks & Ref. \\
\hline \multirow[t]{3}{*}{1} & $\begin{array}{l}\text { a) NBS-celestine } \\
\text { blue }\end{array}$ & 540 & $0.7-6.0$ & $1.6 \times 10^{4}$ & $\begin{array}{l}\text { NBS requires daily } \\
\text { standardisation }\end{array}$ & \multirow[t]{3}{*}{$\begin{array}{l}\text { Sarma et } \\
\text { al. } 2002\end{array}$} \\
\hline & b) Cobalt thiocyante & 610 & $1.5-15.0$ & $7.7 \times 10^{3}$ & $\begin{array}{l}\text { Involves extraction step } \\
\text { with organic solvent, } \\
\text { less sensitive }\end{array}$ & \\
\hline & $\begin{array}{l}\text { c) Ammonium } \\
\text { molybdate }\end{array}$ & 700 & $11.0-150.0$ & $1.0 \times 10^{3}$ & $\begin{array}{l}\text { Requires heating; } \\
\text { least sensitive. }\end{array}$ & \\
\hline 2 & Iron (III)-MBTH & & & & $\begin{array}{l}\text { Longer contact time, } \\
\text { expensive chemical }\end{array}$ & $\begin{array}{l}\text { Sankar et } \\
\text { al. } 2002\end{array}$ \\
\hline \multirow[t]{3}{*}{3} & $\begin{array}{l}\text { a) } \mathrm{KMnO}_{4} \text {-Fast } \\
\text { green } \mathrm{FCF}\end{array}$ & 640 & $1.0-8.0$ & $1.28 \times 10^{4}$ & Less sensitive & \multirow[t]{3}{*}{$\begin{array}{l}\text { Sharma et } \\
\text { al. } 2002\end{array}$} \\
\hline & $\begin{array}{l}\text { b) } \mathrm{KMnO} 4 / \mathrm{NaIO} 4- \\
\mathrm{MBTH}\end{array}$ & 620 & $0.6-6.0$ & $2.02 \times 10^{4}$ & $\begin{array}{l}\text { Longer contact time, } \\
\text { expensive chemical }\end{array}$ & \\
\hline & $\begin{array}{l}\text { c) Iron (III)- } \\
\text { ferricyanide }\end{array}$ & 740 & $9.0-75.0$ & $1.24 \times 10^{3}$ & Less sensitive & \\
\hline \multirow[t]{2}{*}{4} & $\begin{array}{l}\text { a) CAT- } \\
\text { methylorange }\end{array}$ & 520 & $0.2-2.0$ & $5.7 \times 10^{4}$ & \multirow{2}{*}{$\begin{array}{l}\text { Highly sensitive,wide } \\
\text { linear dyanamic ranges, } \\
\text { no heating/extraction, } \\
\text { shorter reaction time } \\
\text { inexpensive chemicals }\end{array}$} & \multirow[t]{2}{*}{$\begin{array}{l}\text { Present } \\
\text { methods }\end{array}$} \\
\hline & $\begin{array}{l}\text { b) CAT- } \\
\text { indigocarmine }\end{array}$ & 610 & $0.5-10$ & $1.5 \times 10^{4}$ & & \\
\hline
\end{tabular}

* MBTH. 3-methylbenzothiazolinone hydrazone; NBS. N-bromosuccinimide.

disadvantage like poor sensitivity, heating or extraction step and/or use of expensive chemical/organic solvent.

In this communication, we report one titrimetric and two spectrophotometric methods for the determination of STV in bulk drug and in pharmaceutical formulations. The methods are based on the oxidation of STV by CAT followed by estimation of unreacted oxidant by iodometric back titration (titrimetry) or reacting with a fixed amount of dye (spectrophotometry). The methods were applied to the determination of STV in different proprietary drugs and were found to yield satisfactory results.

\section{EXPERIMENTAL}

\section{Apparatus}

A Systronics model 106 digital spectrophotometer with 1-cm matched quartz cells was used for all absorbance measurements.

\section{Reagents and materials}

All chemicals used were of analytical reagent grade and distilled water was used to prepare all solutions. Chloramine-T solution $(0.01 \mathrm{M})$ was prepared by dissolving about $2.8 \mathrm{~g}$ of the chemical (Qualigens Fine Chem., Glaxo India Ltd., Mumbai) in water and diluting to 1 litre, and used in titrimetry after standardization ( Berka et al., 1965). For spectrophotometric investigation, the above solution was diluted appropriately with water to get 50.0 and $225.0 \mu \mathrm{g} / \mathrm{mL}$ concentrations for method A and method B, respectively. To prepare $50.0 \mu \mathrm{g} / \mathrm{mL}$ methyl orange for method A, first, a $500.0 \mu \mathrm{g} / \mathrm{mL}$ dye solution was prepared by dissolving $59.0 \mathrm{mg}$ of dye (s.d. Fine Chem Ltd., Mumbai, assay 85\%) in water and diluting to $100 \mathrm{~mL}$ in a calibrated flask, and filtered using glass wool. This was diluted ten-fold with water to get the required concentration. For method B, first, a $1000.0 \mu \mathrm{g} / \mathrm{mL}$ indigo carmine solution was prepared by dissolving $112.0 \mathrm{mg}$ of dye (s.d.Fine-Chem Ltd., Mumbai, 90\% assay) in water and diluting to $100 \mathrm{~mL}$, and filterd. This was appropriately diluted with water to get $200.0 \mu \mathrm{g} / \mathrm{mL}$. Hydrochloric acid $(5.0,2.0$ or $1.0 \mathrm{M})$ was prepared by diluting concentrated acid (s.d. Fine-Chem Ltd., Mumbai, Sp gr 1.18) appropriately with water. Sodium thiosulphate solution $(0.02 \mathrm{M})$ was prepared by dissolving about $5.0 \mathrm{~g}$ of the 
chemical (SISCO Chem, Industries, Mumbai) in 1 litre of water and standardized with pure potassium dichromate iodometrically (Bassett et al., 1978). Aqueous solutions of potassium iodide $(10 \%)$ and starch indicator $(1 \%)$ were prepared in the usual way. Pharmaceutical grade STV, certified to be $99.8 \%$ pure, was received from Cipla India Ltd, Mumbai, India, as gift and was used as received. A 1.0 $\mathrm{mg} / \mathrm{mL}$ solution of STV was prepared by dissolving accurately weighed $250.0 \mathrm{mg}$ of pure drug in water and diluting to $250 \mathrm{~mL}$ with water in a calibrated flask and used for assay by titrimetry. This stock solution $(1000.0 \mu \mathrm{g} / \mathrm{mL})$ was diluted with water to get working concentrations of 5.0 and $20.0 \mu \mathrm{g} / \mathrm{mL} \mathrm{STV}$ for method A and method B, respectively.

\section{Methods}

\section{Titrimetry}

A $10.0 \mathrm{~mL}$ aliquot of pure drug solution equivalent to $1.5-10.0 \mathrm{mg}$ of STV was measured accurately and transferred into a $100 \mathrm{~mL}$ titration flask. Five $\mathrm{mL} 1 \mathrm{M}$ hydrochloric acid followed by $10 \mathrm{~mL}$ of $0.01 \mathrm{M}$ CAT solution were added and kept aside for 10 min with occasional swirling. Then, $5 \mathrm{~mL}$ of $10 \%$ potassium iodide solution were added to the flask and the liberated iodine was titrated with $0.02 \mathrm{M}$ sodium thiosulphate to a starch end point. Ablank titration was run under same conditions. The amount of the drug present in the measured aliquot was calculated from the volume of CAT that has reacted with the drug.

\section{Spectrophotometric method using methyl orange (Method A)}

Aliquots of pure STV solution $(0.4$ to $4.0 \mathrm{~mL}$; $5.0 \mu \mathrm{g} / \mathrm{mL}$ ) were transferred into a series of $10 \mathrm{~mL}$ calibrated flasks and the total volume was adjusted to 4.0 $\mathrm{mL}$ with water. To each flask were added $1 \mathrm{~mL}$ of $5 \mathrm{M}$ hydrochloric acid followed by $1 \mathrm{~mL}$ of CAT solution $(50.0 \mu \mathrm{g} / \mathrm{mL})$. The content was mixed well and the flasks were set aside for $10 \mathrm{~min}$ with occasional shaking. Finally, $1 \mathrm{~mL}$ of $50.0 \mu \mathrm{g} / \mathrm{mL}$ methyl orange solution was added to each flask, diluted to the mark with water and the absorbance of solution was measured at $520 \mathrm{~nm}$ against reagent blank after $10 \mathrm{~min}$.

\section{Spectrophotometry with indigo carmine (Method B)}

Varying aliquots $(0.5-5.0 \mathrm{~mL})$ of standard $20.0 \mu \mathrm{g} / \mathrm{mL}$ STV solution were measured accurately and delivered into a series of $10 \mathrm{~mL}$ calibrated flasks and the total volume was brought to $5.0 \mathrm{~mL}$ with water. To each flask were added $2 \mathrm{~mL}$ each of $2 \mathrm{M}$ hydrochloric acid and $200.0 \mu \mathrm{g} / \mathrm{mL}$
chloramine-T solutions successively; the flasks were let stand for $10 \mathrm{~min}$ with occasional shaking. Then, $1 \mathrm{~mL}$ of $200.0 \mu \mathrm{g} / \mathrm{mL}$ indigo carmine solution was added to each flask, the volume was adjusted to the mark with water and mixed well. The absorbance of each solution was measured at $610 \mathrm{~nm}$ against a reagent blank after $10 \mathrm{~min}$.

In either spectrophotometric method, the concentration of the unknown was read from the calibration graph or computed from the regression equation derived from the Beer's law data.

\section{Assay procedure for formulations}

An amount of finely ground tablet/capsule powder equivalent to $100.0 \mathrm{mg}$ of STV was accurately weighed into a $100 \mathrm{~mL}$ calibrated flask, $60 \mathrm{~mL}$ of water added and shaken for $20 \mathrm{~min}$. Then, the volume was made up to the mark with water, mixed well, and filtered using a Whatman No 42 filter paper. First $10 \mathrm{~mL}$ portion of the filtrate was discarded and a suitable aliquot of the subsequent portion $(1.0 \mathrm{mg} / \mathrm{mL}$ STV) was taken for assay by titrimetric procedures. The filtrate was diluted appropriately to get 5.0 and $20.0 \mu \mathrm{g} / \mathrm{mL} \mathrm{STV} \mathrm{concentrations} \mathrm{for} \mathrm{analysis} \mathrm{by}$ spectrophotometric method A and method B, respectively.

\section{RESULTS AND DISCUSSIONS}

The proposed methods are based on the oxidation of STV by CAT in $\mathrm{HCl}$ medium and the reaction is followed by titrimetry and spectrophotometry for quantization purposes. In titrimetry, the unreacted CAT is determined iodometrically, and in spectrophotometric methods, the same is determined by reacting with a fixed amount of either methyl orange or indigo carmine. The latter methods make use of the bleaching action of chloramine-T on either dye, the decolouration being caused by the oxidative destruction of the dye.

\section{Optimisation of experimental conditions}

\section{Titrimetry}

The reaction stoichiometry was found to be $1: 1$ (STV: CAT) which was unaffected in the presence of 3 to $8 \mathrm{~mL}$ of $1 \mathrm{M} \mathrm{HCl}$ in a total volume of $25 \mathrm{~mL}$ and hence $5 \mathrm{~mL}$ of $1 \mathrm{M}$ $\mathrm{HCl}$ was chosen as the optimum volume. The oxidation reaction was found to be complete in $10 \mathrm{~min}$ and contact time upto $30 \mathrm{~min}$ had no effect on the stoichiometry or the results. A $10 \mathrm{~mL}$ volume of $0.01 \mathrm{MCAT}$ solution was found adequate for the quantitative oxidation of STV in 1.5 to $10.0 \mathrm{mg}$ range. The linearity between the amount of drug and titration end point is apparent from the calculated correlation coefficient of -0.9964 suggesting that the 
reaction between STV and CAT proceeds stoichiometrically in the ratio of $1: 1$, in the optimum range (1.5$10.0 \mathrm{mg}$ ). Based on the reaction stoichiometry, a tentative reaction scheme shown in Figure 1 is suggested.

\section{Spectrophotometry}

In the proposed spectrophotometric methods, the ability of CAT to effect oxidation of STV and irreversibly destroy methyl orange or indigo carmine to colourless products in acid medium has been used. STV when added in increasing concentrations to a fixed concentration of CAT, consumes the latter and there will be a concomitant decrease in its concentration. When a fixed concentration of either dye is added to decreasing concentrations of CAT, a concomitant increase in the concentration of dye results and a proportional increase in the absorbance at the respective $\lambda_{\text {max }}$ is observed with increasing concentration of STV.

Preliminary experiments were performed to fix the upper limits of the dyes that could be determined spectrophotometrically, and these were found to be 5.0 and $20.0 \mu \mathrm{g} / \mathrm{mL}$ for methyl orange and indigo carmine, respectively. A CAT concentration of $5.0 \mu \mathrm{g} / \mathrm{mL}$ was found to irreversibly destroy the red colour of $5.0 \mu \mathrm{g} / \mathrm{mL}$ methyl orange whereas $20.0 \mu \mathrm{g} / \mathrm{mL}$ CAT was required to bleach the blue colour due to $22.5 \mu \mathrm{g} / \mathrm{mL}$ indigo carmine. Hence, different amounts of STV were reacted with $1 \mathrm{~mL}$ of $50.0 \mu \mathrm{g} / \mathrm{mL}$ CAT in method A and $1 \mathrm{~mL}$ of $225.0 \mu \mathrm{g} / \mathrm{mL}$ CAT in method B followed by determination of the residual oxidant as described under the respective procedures.

For both oxidation of STV and bleaching of dye by
CAT, hydrochloric acid medium was found to be ideal. One $\mathrm{mL}$ of $5 \mathrm{M}$ hydrochloric acid for method A and $2 \mathrm{~mL}$ of $2 \mathrm{M}$ $\mathrm{HCl}$ for method $\mathrm{B}$, in a total volume of $\sim 4-5 \mathrm{~mL}$ were adequate for the oxidation step which was complete in $10 \mathrm{~min}$ in both methods and the same quantity of acid was employed for the estimation of the dye. Contact time of $10 \mathrm{~min}$ is not critical and any delay upto $30 \mathrm{~min}$ had no effect on the absorbance. The absorbance of either dye colour was stable for several hours in the presence of reaction product.

\section{Analytical data}

A linear correlation was found between absorbance at $\lambda_{\text {max }}$ and concentration of STV. The graphs showed negligible intercept and are described by the equation:

$$
\mathrm{Y}=\mathrm{a}+\mathrm{bX}
$$

(where $\mathrm{Y}=$ absorbance of 1 -cm layer of solution; $\mathrm{a}=$ intercept; $\mathrm{b}=$ slope and $\mathrm{X}=$ concentration in $\mu \mathrm{g} / \mathrm{mL}$ ). Regression analysis of the Beer's law data using the method of least squares was made to evaluate the slope (b), intercept (a) and correlation coefficient(r) for each system and the values are presented in Table II. The optical characteristics such as Beer's law limits, molar absorptivity and Sandell sensitivity values of both methods are also given in Table II. The limits of detection (LOD) and quantitation(LOQ) calculated according to ICH guidelines( ICH guidelines, 1996) are also presented in Table II and reveal the very high sensitivity of the spectrophotometric methods.

TABLE II - Analytical and regression parameters of spectrophotometric methods

\begin{tabular}{lll}
\hline Parameter & Method A & Method B \\
\hline$\lambda_{\text {max }}, \mathrm{nm}$ & 520 & 610 \\
Beer's law limits, $\mu \mathrm{g} / \mathrm{mL}$ & $0.2-2.0$ & $1.0-10.0$ \\
Molar absorptivity, $\mathrm{L} / \mathrm{mol} / \mathrm{cm}$ & $5.7 \times 10^{4}$ & $1.5 \times 10^{4}$ \\
Sandell sensitivity, $\mu \mathrm{g} / \mathrm{cm}^{2}$ & 0.004 & 0.015 \\
Limit of detection, $\mu \mathrm{g} / \mathrm{mL}$ & 0.03 & 0.12 \\
Limit of quantification, $\mu \mathrm{g} / \mathrm{mL}$ & 0.10 & 0.35 \\
Regression equation, $\mathrm{Y}^{*}$ & & \\
Intercept (a) & -0.0028 & -0.002 \\
Slope (b) & 0.2595 & 0.0651 \\
Correlation coefficient, $(\mathrm{r})$ & 0.9995 & 0.9984 \\
$\mathrm{~S}_{\mathrm{a}}$ & 0.006 & 0.012 \\
$\mathrm{~S}_{\mathrm{b}}$ & 0.003 & 0.001 \\
\hline
\end{tabular}

${ }^{*} \mathrm{Y}=\mathrm{a}+\mathrm{bX}$, where $\mathrm{Y}$ is the absorbance and $\mathrm{X}$ concentration in $\mu \mathrm{g} / \mathrm{mL} ; \mathrm{S}=$ Standard deviation of intercept; $\mathrm{S}_{\mathrm{b}}=$ Standard deviation of slope. 


\section{Method Validation}

Intra-day and inter-day precision

To evaluate the precision of the methods, pure drug solution at three different levels (within the working limits) was analysed, each determination being repeated seven times. The relative standard deviation $(\%)$ values were $\leq 2.0$ and indicate the high precision for the methods. For a better picture of reproducibility on a day-to-day basis, a series of experiments were performed in which standard drug solution at three different levels was determined each day for five days with all solutions being prepared afresh each day. The day-to-day relative standard deviation values were in the range of 3.2-3.7\% and represent the best appraisal of the methods in routine use.

\section{Application to analysis of commercial samples}

In order to check the validity of the proposed methods, STV was determined in some commercial formulations. Table III gives the results of the determination from which it is clear that there is close agreement between the results obtained by the proposed methods and the label claim. The results were also compared statistically by a Student's t- test for accuracy and variance ratio $\mathrm{F}$ - test for precision with those of the literature method (Sankar et al., 2002) at 95\% confidence level. The calculated t- and F-values (Table III) did not exceed the tabulated values ( $\mathrm{t}=2.77, \mathrm{~F}=6.39)$, indicating that there was no significant difference between the proposed methods and the reference method in respect to accuracy and precision.

The accuracy and validity of the proposed methods were further ascertained by performing recovery studies. Pre-analysed tablet or capsule powder was spiked with pure STV at three different levels and the total was found by the proposed methods. Each determination was repeated three times. The recovery of the pure drug added was quantitative and revealed that co-formulated substances such as talc, starch, gum acacia, lactose, sodium alginate, magnesium stearate, calcium carbonate, calcium gluconate and calcium dihydrogenorthophosphate did not interfere in the determination. The results of recovery study are compiled in Table IV.

\section{CONCLUSIONS}

Three useful micro methods for the determination of STV have been developed and validated. The methods are simple and rapid taking not more than 10-15 min for the assay. The titrimetric method is the first ever proposed for stavudine and is applicable over range 1.5 to $10.0 \mathrm{mg}$. Both the spectrophotometric methods are more sensitive than the existing UV and HPLC methods and are free from such experimental variables as heating or extraction step. The methods rely on the use of simple and cheap chemicals and techniques but provide a sensitivity comparable to that

TABLE III - Results of determination of stavudine in formulations and statistical comparison with the literature method

\begin{tabular}{|c|c|c|c|c|c|}
\hline \multirow[b]{2}{*}{ Brand name ${ }^{\#}$} & \multirow[b]{2}{*}{$\begin{array}{l}\text { Nominal } \\
\text { amount (mg) }\end{array}$} & \multicolumn{3}{|c|}{$\%$ Found $* \pm S D$} & \multirow[b]{2}{*}{ Method B } \\
\hline & & $\begin{array}{l}\text { Literature } \\
\text { method }\end{array}$ & Titrimetry & Method A & \\
\hline \multirow[t]{2}{*}{$\begin{array}{l}\text { VIROSTAV } \\
\text { (Tablets) }\end{array}$} & 30.0 & $99.66 \pm 0.82$ & $\begin{array}{l}100.30 \pm 1.16 \\
t=1.02 \\
F=2.00\end{array}$ & $\begin{array}{l}100.20 \pm 1.46 \\
t=0.75 \\
F=3.17\end{array}$ & $\begin{array}{l}99.95 \pm 0.66 \\
t=0.62 \\
F=1.54\end{array}$ \\
\hline & 40.0 & $99.91 \pm 0.56$ & $\begin{array}{l}100.30 \pm 0.45 \\
t=1.21 \\
F=1.55\end{array}$ & $\begin{array}{l}98.62 \pm 1.01 \\
t=2.60 \\
F=3.25\end{array}$ & $\begin{array}{l}100.10 \pm 1.02 \\
t=0.38 \\
F=3.32\end{array}$ \\
\hline \multirow[t]{2}{*}{$\begin{array}{l}\text { STAG }^{\mathrm{b}} \\
\text { (Capsules) }\end{array}$} & 30.0 & $102.3 \pm 0.51$ & $\begin{array}{l}101.60 \pm 0.39 \\
t=2.46 \\
F=1.71\end{array}$ & $\begin{array}{l}101.95 \pm 1.02 \\
t=0.72 \\
F=4.00\end{array}$ & $\begin{array}{l}100.60 \pm 1.16 \\
t=0.57 \\
F=5.17\end{array}$ \\
\hline & 40.0 & $100.5 \pm 0.62$ & $\begin{array}{l}101.10 \pm 0.55 \\
t=1.61 \\
F=1.27\end{array}$ & $\begin{array}{l}99.95 \pm 1.32 \\
t=0.90 \\
F=4.53\end{array}$ & $\begin{array}{l}101.90 \pm 1.33 \\
t=2.27 \\
F=4.60\end{array}$ \\
\hline
\end{tabular}

*Mean value of five determinations; \#Marketed by: a. Cross Lands.; b. Genix Ltd.; Tabulated t-value at 95\% confidence level is 2.77; Tabulated F-value at 95\% confidence level is 6.39 . 
TABLE IV - Recovery of a standard STV solution added to samples and analysed by the proposed methods

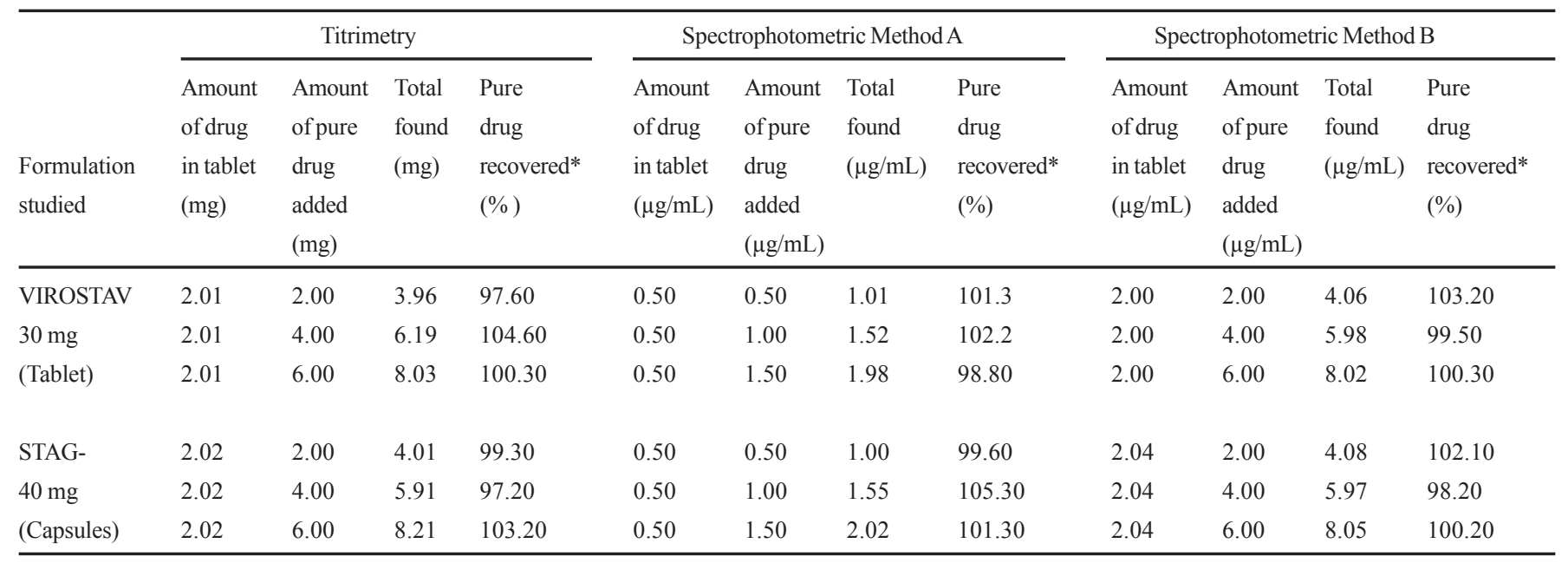

* Mean value of three determinations

achieved by sophisticated and expensive technique like HPLC. Thus, they can be used as alternatives for rapid and routine determination of bulk sample and tablets.

\section{RESUMO}

\section{Uso de cloramina-T e de dois corantes na determina- ção sensível de estavudina em medicamentos}

Descrevem-se três novos métodos para o ensaio de estavudina (STV) na matéria-prima e nas formulações utilizando-se clroamina-T (CAT) e dois corantes, alaranjado de metila e indigo carmim como reagentes. A titulação envolve o tratamento de STV com excesso medido de CAT em meio de ácido clorídrico, e, quando a oxidação se completar, o oxidante que não reagiu é determinado iodometricamente. Os métodos espectrofotométricos compreendem a adição de excesso conhecido de CAT ao STV em ácido clorídrico, seguida da determinação do oxidante residual por meio da reação com quantidade fixada de alaranjado de metila, medindo-se a absorvância a $520 \mathrm{~nm}$ (Método A) ou índigo carmim, medindo-se a absorvância a $610 \mathrm{~nm}$ (Método B). Em todos os métodos, a quantidade de CAT que reagiu corresponde à quantidade de STV. No método titulométrico, a reação segue a estequiometria 1:1 (STV:CAT) e é aplicável na faixa de 1,5 a $10 \mathrm{mg}$ de STV. Nos métodos espectrofotométricos, a absorvância aumenta linearmente com a concentração de STV. Os sistemas obedecem a lei de Beer nos intervalos de 0,2 a 2,0 $\mathrm{mg} / \mathrm{mL}$ e 1,0 a 10,00 mg/mL para os métodos $A$ e $B$, respectivamente, e os valores de sensibilidade de Sandell correspondentes são 0,004 e 0,015 $\mu \mathrm{g} / \mathrm{cm}^{2}$. Os li- mites de detecção e de quantificação são apresentados para ambos os métodos. A precisão e a exatidão intra-dia e inter-dia dos métodos desenvolvidos são avaliadas de acordo com as normas ICH. Os métodos foram aplicados com êxito aos ensaios de STV em comprimidos e em cápsulas e os resultados foram comparáveis com aqueles obtidos com o método de referência, utilizando-se o teste t de Student e o teste F. Não se observou interferência dos adjuvantes comuns em comprimidos. A exatidão e a confiabilidade dos métodos foram ajustadas por meio de experimentos de recuperação via método de adição de padrão.

UNITERMOS: Estavudina. Titulometria. Espectrofotometria. Cloramina-T.

\section{REFERENCES}

BASSETT, J.; DENNEY, R. C.; JEFFERY, G. H.; MENDHAM, J. Vogel's text book of quantitative inorganic analysis. London: Longman Group Ltd., 1978. p.376.

BEZY, V.; MORIN, P.; COURBE, P.; LELEU, G. AGROFOGLIO, L. Simultaneous analysis of several antiretroviral nucleosides in rat-plasma by high performance liquid chromatography with uv using acetic acid/hydroxylamine buffer. J. Chromatogr. B., v.821, p.132-143, 2005.

BERKA, A.; VULTERIN, J., ZYKA, J. Newer redox titrants. London: Pergamon Press,1965. p.38. 
COMPAIN, S.; SCHLEMMER, D.; LEVI, M.; PRUVOST, A.; GOUJARD, C.; GRASSI, J., BENECH, H. Development and validation of a liquid chromatographic/ tandem mass spectrometric assay for the quantitation of nucleoside HIV reverse transcriptase inhibitors in biological matrices. J. Mass Spectrom., v.40, p.9-18, 2005.

CONTRERAS, J.; GONZALEZ, H.; MENENDEZ, R., LOPEZ, M. Development and validation of a reversed phase liquid chromatographic method for the analysis of $\mathrm{D}$ and $\mathrm{T}$ (stavudine) in rat plasma. $J$. Chromatogr B., v.801, p.199-203, 2004.

DJURDJEVIC, P.; LABAN, A.; MARKOVIC, S., JELIKIKSTANKOV, M. Chromometric optimization of a RPHPLC method for the simultaneous analysis of abacavir, lamivudine and zidovudine in tablets. Anal. Lett., v.37, p.2649-2667, 2004.

DUNGE, A.; SHARDA, N.; SINGH, B., SINGH, S. Establishment of inherent stability of stavudine and development of a validated stability-indicating HPLC assay method. J. Pharm. Biomed. Anal., v. 37, p. 11151119, 2005.

FAN, B.; BARTLETT, M. G.; STEWART, J. T. Determination of lamivudine/stavudine/efavirenz in human serum using liquid chromatography/electrospray tandem mass spectrometry with ionization polarity switch. Biomed. Chromatogr., v.16, p.383-389, 2002.

FAN, B., STEWART, J. T. Determination of stavudine/ didanosine/saquinavir and stavudine/didanosine/efavirenz in human serum by micellar electrokinetic chromatography. J. Liq. Chromatogr. Rel. Technol., v.25, p.937-947, 2002.

HUANG, Y.; ZURLINDEN, E.; LIN E.; LI, X.; TOKUMOTO, J.; GOLDEN, J.; MURR, A.; ENGSTORM, J., CONTE, J. Liquid chromatographictandem mass spectrometric assay for the simultaneous determination of didanosine and stavudine in human plasma, Branchoalveolar lavage fluid, alveolar cells, periphera blood mononuclear cells, seminal plasma, cerebrospinal fluid and tonsil tissue. J. Chromatogr. B., v. 799 p. 51-61, 2004.
INTERNATIONAL CONFERENCE ON HARMONIZATION OF TECHNICALREQUIREMENTS FOR REGISTRATION OF PHARMACEUTICALS FOR HUMAN USE. ICH Harmonised Tripartite Guideline. Validation of Analytical Procedures: Text and Methodology Q2(R1). Complementary Guideline on Methodology. London: [s.n.], 1996.

KAUL, N.; AGARAWAL, H.; PARADKAR, A. R.; MAHADIK, K. R. The ICH guidance in practice: stress degradation studies on stavudine and development of a validated specific stability-indicating HPTLC assay method. J. Chromatogr. Sci., v. 43, p.406-415, 2005.

MERCK INDEX. $12^{\text {th }}$ ed. White House Station: Merck and Co. Inc, 1996. p.1502.

PAI, N. R.; DESAI, A. S. Simultaneous estimation of some antiretroviral drugs from tablets by reverse phase HPLC method. Indian Drugs, v. 40, p.111-114, 2003.

PEREIRA, E. A.; MICKE, G. A.; TAVARES, M. F. M. Determination of antiretroviral agents in human serum by capillary electrophoresis. J. Chromatogr. A., v.1091, p. 169-176, 2005.

RAICES, R. S. L.; SALVADORI, M. C.; ESTRELA, R. C. E.; DEAQUIN NETO, F. R., SQUREZ-KURTZ, G. Determination of stavudine in human serum by on-line solid-phase extraction coupled to HPLC with electrospray ionization tandem mass spectrometry: application to a bioequivalence study. Rapid commun. Mass. Spectro., v.17, p. 1611-1618, 2003.

REZK, N. L.; TIDWELL, R. R.; RICHARD, R.; KASHUBA, A. D. M. Simultaneous determination of six HIV nucleoside analogue reverse transcriptase inhibitors and nevirapine by HPLC with ultraviolet absorbance detection. J. Chromatogr B., v.791, p. 137-147, 2003.

SABLON, M.; CONTRERAS, J.; DIAZ, O.; PEREZ, R.; VELEZ, H.; RODRIGUEZ-TANTY, C. Quantification of an antiviral drug (d 4T) by an HPLC procedure. Acta Pharma. Bonaeresse,. v.23, p.81-88, 2004.

SANKAR, D. G.; REDDY, M. V. V. N.; KUMAR, J. M. R.; MURTHY, T. K. UV spectrophotometric determination of some anti-HIV drugs. Asian J. Chem., v. 14, p.433-436, 2002. 
SANKAR, D. G.; REDDY, M. V. V. N.; KUMAR, J. M. R.; MURTHY, T. K. Spectrophotometric determination of lamivudine and stavudine. Indian J. Pharm. Sci., v. 64, p.504-506, 2002.

SARMA, C. S. N.; SASTRI, C. K.; SASTRY, C. S. P. Simple oxidimetric methods for determination of stavudine or lamivudine. Asian J. Chem., v.14, p.683-690, 2002.

SARMA, C. S. N.; SASTRI, C. K.; SASTRY, C. S. P. Determination of stavudine and lamivudine by visible spectrophotometry. Acta Ciencia Indica Chem., v.28, p.221-225,2002.

SOLDIN, S. J.Anti-retroviral analysis by mass spectrometry. PCT Int Appl Patent No Wo 2004089182, 2004.

TRAN, T. T.; ROBBINS, B. L.; PINKERTON, F. H.; FERRUA. B.; GRASSI, J.; FRIDLAND, A. A new sensitive cartridge-RID method for determination of stavudine (D 4 T) triphosphate in human cells in vivo. Antiviral Res., v.58, p.125-129, 2003.

UNITED STATES PHARMACOPEIA. United States Pharmacopeial Convention Inc. Rockville: 2006. p. 20052007.
VERWEIJ-VAN WISSEN, C. P. W. G. M.; AARNOUTSE, R. E.; BURGER, D. M. Simultaneous determination of the HIV nucleoside analogue reverse transcriptase inhibitors lamivudine, didanosine, stavudine, zidovudine and abacavir in human plasma by reverse phase HPLC. J. Chromatogr. B., v.816, p.121-129, 2005.

VOLOSOV, A.; ALEXANDER, C.; TING, L.; SOLDIN, S. J. Simple rapid method for quantification of antiretrovirals by liquid chromatography-tandem mass spectrometry. Clin. Biochem., v.35, p.99-103, 2002.

WANKHEDE, S. B.; GUPTHA, K. R.; WADODKAR, S. G. Simultaneous high performance thin layer chromatographic estimation of lamivudine and stavudine in tablet dosage forms. Indian J. Pharm. Sci., v. 67, p.9697, 2005.

WIESNER, J. L.; SUTHERLAND, F. C. W.; SMIT, M. J.; VAN ESSEN, G. H.; HUNDT, H. K. L.; SWART, K. J.; HUNDT, A. F. Sensitive and rapid liquidchromatography-tandem mass spectrometry method for the determination of stavudine in human plasma. $J$. Chromatogr. B., v.773, p.129-134,2002.

ZHANG, M.; CEN, J. Determination of stavudine and its related substances by HPLC. Zhongguo Yiyao Gongye Zazhi v.34, p.402-403, 2003.

Recebido para publicação em 04 de dezembro de 2006. Aceito para publicação em 01 de agosto de 2007. 